\title{
PKM KULINER MAKANAN KECIL DI JALAN BIBIS RAYA KASIHAN BANTUL DAERAH ISTIMEWA YOGYAKARTA
}

\author{
Barbara Gunawan ${ }^{1}$ \\ ${ }^{1}$ Fakultas Ekonomi dan Bisnis, Universitas Muhammadiyah Yogyakarta \\ e-mail: barbaragunawan@yahoo.co.id
}

\begin{abstract}
Abstrak
Sasaran program PKM ini adalah kelompok masyarakat usaha kecil/industri rumahan penjual dan pembuat makanan kecil. Tujuan program adalah untuk mengembangkan masyarakat yang mandiri secara ekonomi. Mitra usaha dalam program ini adalah usaha kecil pembuatan dan penjualan kue kecil. Permasalahan yang dihadapi oleh Mitra 1 dan Mitra 2 adalah a) Tempat penyajian makanan yang kurang layak dan tidak rapi, b) Tidak ada identitas nama toko, c) meja etalase yang kurang memadai, d) perlengkapan dari pembuat makanan yang kurang layak dan bukan food grade, e) Pencatatan yang belum rapi, dan f) kurangnya edukasi tentang kebersihan. Target dan luaran yang dihasilkan dari program pengabdian masyarakat PKM Kuliner Makanan Kecil di Jalan Bibis Raya Kasihan Bantul Daerah Istimewa Yogyakarta adalah a) Tempat penyajian makanan yang layak dan rapi, b) Ada banner, spanduk, dan taplak meja dengan informasi nama toko, c) Meja etalase yang rapi dan bersih, d) Tempat makanan dari supplier yang tertutup dan ada simbol food grade, e) Pencatatan yang rapi, dan f) Pemahaman akan kebersihan penyajian dan lingkungan sekitar toko. Metode yang dipakai untuk mencapai tujuan tersebut adalah a) Pengadaan tempat penyajian makanan, b) Perancangan dan pembuatan banner, spanduk, dan taplak meja, c) Pengadaan meja etalase yang rapi, d) Pengadaan tempat makanan untuk supplier, e) Pelatihan pencatatan keuangan, dan f) Focus discussion group tentang kebersihan penyajian dan lingkungan sekitar toko. Hasil akhir dari program ini adalah tempat penyajian makanan yang rapi, terpasang spanduk dan taplak meja dengan identitas mitra; tersedia meja yang rapi, tersedia tempat makanan dengan simbol food grade, terselenggara pelatihan pencatatan keuangan, dan terselenggara focus discussion group. Setelah adanya identitas toko, sudah terjadi beberapa kali pesanan snack box yang tentunya akan meningkatkan pendapatan Mitra.
\end{abstract}

Kata Kunci: Makanan Kecil, Kuliner, Bibis Raya

\section{A. Pendahuluan}

Kuliner makanan kecil berupa jajan pasar atau kue basah dapat dengan mudah dijumpai di Yogyakarta, beberapa diantaranya adalah kuliner yang terdapat di sepanjang Jalan Bibis Raya, Tamantirto, Kasihan, Bantul, Yogyakarta.

Seiring dengan semakin berkembangnya Kecamatan Kasihan, diikuti dengan bertambahnya perumahan, dan beriringan dengan banyaknya penduduk, semakin bertambah 
pula ragam kuliner yang ada di Jalan Bibis Raya. Paling tidak ada lebih dari 20 pedagang makanan kecil berupa jajan pasar atau kue basah di sepanjang Jalan Bibis Raya, Tamantirto, Kasihan, Bantul, Daerah Istimewa Yogyakarta. Dua diantaranya menjadi Mitra dalam Pengabdian Masyarakat ini, dimana satu Mitra berada di timur Balaidesa, sedangkan 1 Mitra lainnya berada di barat Balaidesa Tamantirto.

Mitra 1 (Ibu Nur Yanti) dan Mitra 2 (Ibu Erni) menjual makanan kecil berupa kue basah yang buka setiap hari pada pukul 05.00 hingga 12.00 siang. Ibu Nur Yanti sebagai pemilik toko hanyalah sebagai penjual saja, setiap hari Ibu Nur Yanti menerima titipan dari para supplier pembuat kue. Setiap hari, Mitra 1 menerima titipan makanan kecil dari sekitar 50 supplier, sedangkan Mitra 2 menerima titipan dari sekitar 30 supplier. Secara tidak langsung Mitra dalam pengabdian ini juga adalah supplier yang menitipkan makanan kecil pada Mitra 1 dan Mitra 2.

Permasalahan yang dihadapi oleh Mitra 1 dan Mitra 2 untuk aspek produksi yaitu tidak ada kontrol dari penjual akan produk yang dititipkan, karena penjual hanya menjual saja tanpa mengetahui cara memproduksinya. Dari aspek pemasaran dan akuntansi, permasalahan Mitra adalah a) Tempat penyajian makanan yang kurang layak dan tidak rapi, b) Tidak ada identitas nama toko, c) meja etalase yang kurang memadai, d) perlengkapan dari pembuat makanan yang kurang layak dan bukan food grade, e) Pencatatan yang belum rapi, dan f) kurangnya edukasi tentang kebersihan. Maka dari itu perlu adanya pembenahan baik secara produk maupun brand karena kualitas produk merupakan salah satu faktor yang mempengaruhi kepuasan konsumen (Maria \& Anshori, 2013). Kondisi Mitra 1 dan Mitra 2 tampak pada Gambar 1.

Adapun menurut Badan Pengawas Obat dan Makanan (BPOM) Republik Indonesia standarisasi produksi pangan yang baik setidaknya memperhatikan hal-hal sebagai berikut: 1) Lokasi dan lingkungan produksi, 2) Bangunan dan fasilitas, 3) Peralatan produksi, 4) Suplai air atau sarana penyediaan air, 5) Fasilitas dan kegiatan higiene dan sanitasi, 6) Kesehatan dan higiene karyawan, 7) Pemeliharaan dan program higiene dan sanitasi, 8) Penyimpanan, 9) Pengendalian proses, 10) Pelabelan pangan, 11) dan Pengawasan oleh penanggung jawab. 

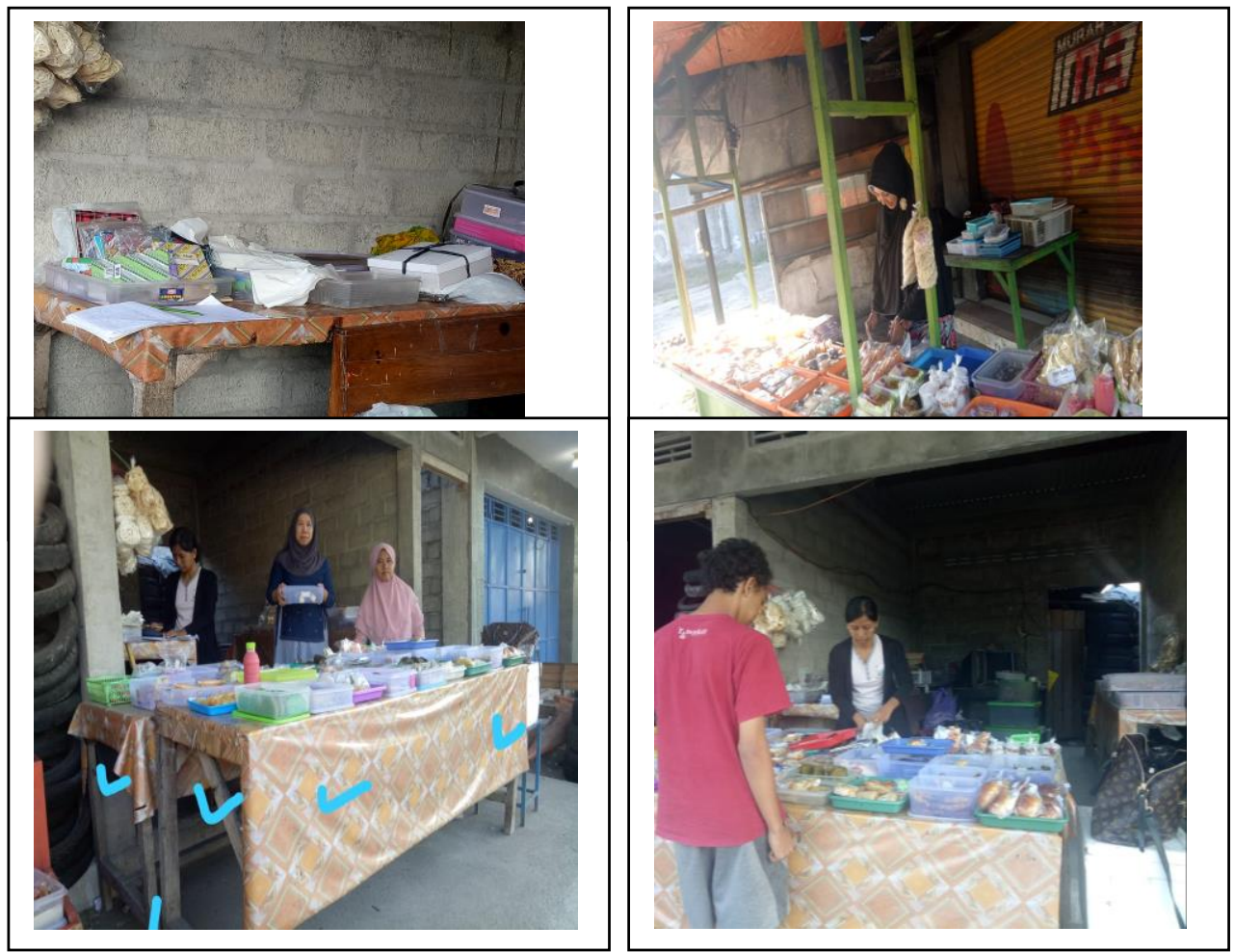

Gambar 1. Kondisi Mitra 1 dan Mitra 2

Produk yang dijual Mitra adalah berupa makanan kecil (kue basah) sangat banyak diminati konsumen, terutama anak sekolah yang akan dibawa sebagai bekal, bagi keluarga makanan tersebut juga sebagai camilan saat sarapan atau suguhan untuk tamu. Adapun jenis kue yang dijual diantaranya adalah kelepon, kue lapis, putu ayu, dadar gulung, tahu isi, lemper, aremarem, kue lumpur, dan lain-lain yang tampak pada Gambar 2. Kue basah tersebut diproduksi oleh supplier di rumah masing-masing untuk kemudian dititipkan kepada Mitra 1 dan Mitra 2 pada pagi hari untuk kemudian diambil kembali pada sekitar pukul 12.00 siang. 

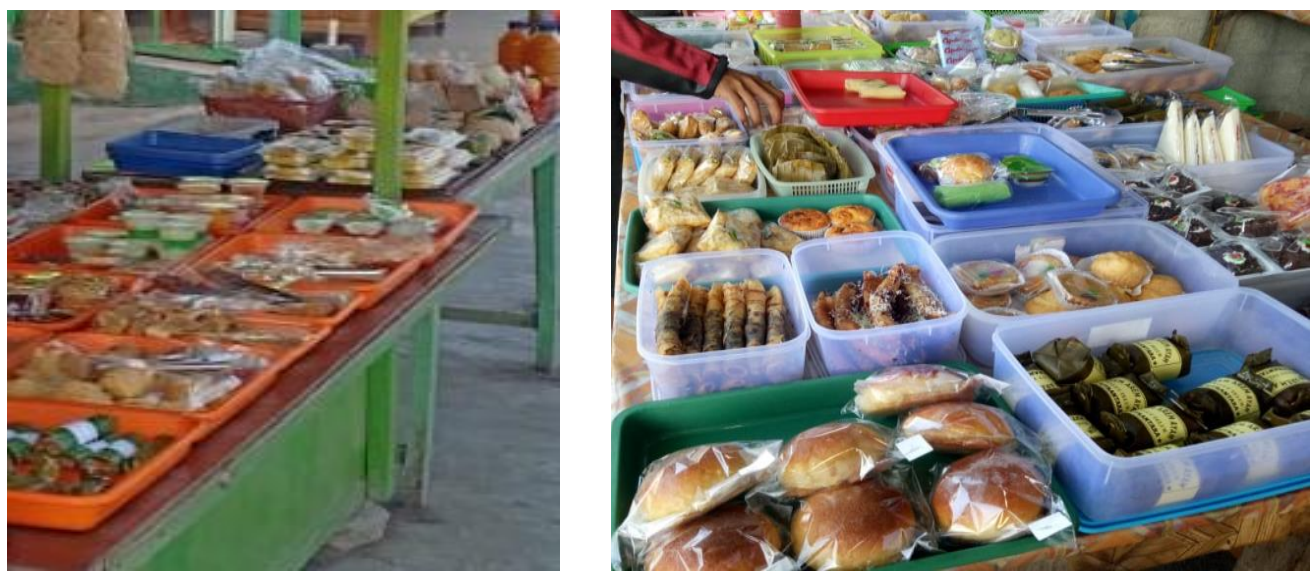

Gambar 2. Produk Kue Jajan Pasar

\section{B. Masalah}

1. Aspek Produksi

Permasalahn yang dihadapi Mitra untuk aspek produksi adalah tidak ada kontrol dari penjual akan produk yang dititipkan, karena penjual hanya menjual saja tanpa mengetahui cara memproduksinya, sehingga tidak dapat diketahui aspek kebersihan maupun aspek kehalalan produk.

2. Aspek manajemen pemasaran

Permasalahan Mitra 1 dan Mitra 2 dari aspek pemasaran adalah:

a. Tempat penyajian makanan yang kurang layak dan tidak rapi, tempat penyajian makanan hanya berupa nampan yang mayoritas adalah milik supplier berupa nampan yang terbuat dari bahan daur ulang. Makanan disajikan secara terbuka tanpa penutup, padahal beberapa makanan tanpa bungkus plastik, sementara toko berada di pinggir jalan yang dilalui oleh kendaraan yang berpotensi menimbulkan debu.

b. Tidak ada identitas nama toko. Baik Mitra 1 maupun Mitra 2 tidak membuat identias toko secara lengkap, sehinga sulit bagi calon customer potensial untuk mencari lokasi toko.

c. Meja etalase yang kurang memadai, Meja etalase terbuat dari papan dengan ditutupi taplak seadanya yang tidak layak dan kurang bersih.

d. Perlengkapan dari supplier pembuat makanan yang kurang layak dan bukan food grade.

e. Pencatatan yang belum rapi. Penjual hanya mencatat seadanya jumlah titipan kue-kue. 
f. Kurangnya edukasi tentang kebersihan. Belum ada edukasi tentang faktor kebersihan, baik saat pembuatan maupun penyajian.

\section{Metode Pelaksanaan}

Program pengabdian dilaksanakan melalui langkah-langkah berikut ini:

\section{Pemilihan Sasaran}

Awalnya tim pengabdi melakukan observasi pada beberapa lokasi penjual makanan kecil yang terdapat di di sekitar jalan Bibis Raya, Tamantirto, Kasihan, Kabupaten Bantul Propinsi DIY. Setelah observasi dilakukan, dilanjutkan dengan memilih mitra yang berminat dan layak bekerjasama dengan tim pengabdi. Setelah melalui berbagai pertimbangan kelayakan, maka sasaran pada kegiatan pengabdian ini adalah Mitra 1 milik Ibu Nur Yanti yang terletak disisi utara jalan Bibis Raya, dan berjarak kira-kira 3 kilometer dari Universitas Muhammadiyah Yogyakarta. Adapun Mitra 2 dalah usaha milik Ibu Erni Andriani yang juga menjual makanan kecil, berada di sisi selatan jalan Bibis Raya, berjarak kira-kira 2 kilometer dari Universitas Muhammadiyah Yogyakarta. Jarak antara Mitra 1 dan Mitra 2 adalah 1,5 kilometer. Berbagai permasalahan yang dihadapi mitra dapat digolongkan menjadi dua aspek kegiatan, yaitu 1) aspek produksi dan 2) aspek manajemen pemasaran

2. Mengidentifikasi Masalah

Langkah selanjutnya yang dilakukan pengabdi adalah mengidentifikasi masalah yang ada pada mitra. Masalah-masalah yang didapatkan pada mitra tersebut selanjutnya digolongkan dalam dua aspek permasalahan, yaitu aspek produksi serta aspek manajemen pemasaran dan akuntansi.

3. Menyampaikan Tawaran Solusi Kepada Mitra

Setelah mengidentifikasi masalah selanjutnya adalah memberikan tawaran solusi kepada mitra atas persoalan yang mereka alami. Langkah ini diharapkan dapat menjadi jalan keluar bagi mitra dalam menghadapi persoalan mereka selama ini.

Metode pendekatan yang ditawarkan untuk menyelesaikan persoalan mitra yang telah disepakati bersama untuk segi utama dalam kurun waktu realisasi program PKM.

1. Metode Pelaksanaan yang Ditawarkan dalam Bidang Produksi dan Telah Disepakati Pengadaan (menambah/mengganti) alat saji makanan

2. Metode Pelaksanaan yang Ditawarkan dalam Bidang Produksi dan Telah Disepakati 
a. Pembuatan banner, taplak meja, dan spanduk yang namanya akan disepakati bersama Mitra

b. Merancang dan membuat stiker merk

c. Pelatihan menghitung harga pokok produksi dan laporan keuangan

d. Focus discussion group untuk kebersihan, kerapian, dan produk halal

\section{Pembahasan}

\section{Rancangan Logo Taplak, Banner, dan Spanduk}

Kegiatan diawali mengukur kebutuhan taplak, banner, stiker dan spanduk untuk kedua Mitra, dilanjutkan dengan membuat beberapa alternative rancangan logo dan gambar, kemudian dari beberapa alternatif tersebut didiskusikan dengan Mitra. Dalam hal merancang logo dan gambar, ada beberapa makna dan filosofi yang melandasi, hingga terbentuk dan terpilihlah logo dan merk yang akan dipakai oleh Mitra 1 dan Mitra 2. Adapun rancangan logo, gambar, dan ukuran tampak pada Gambar 3.

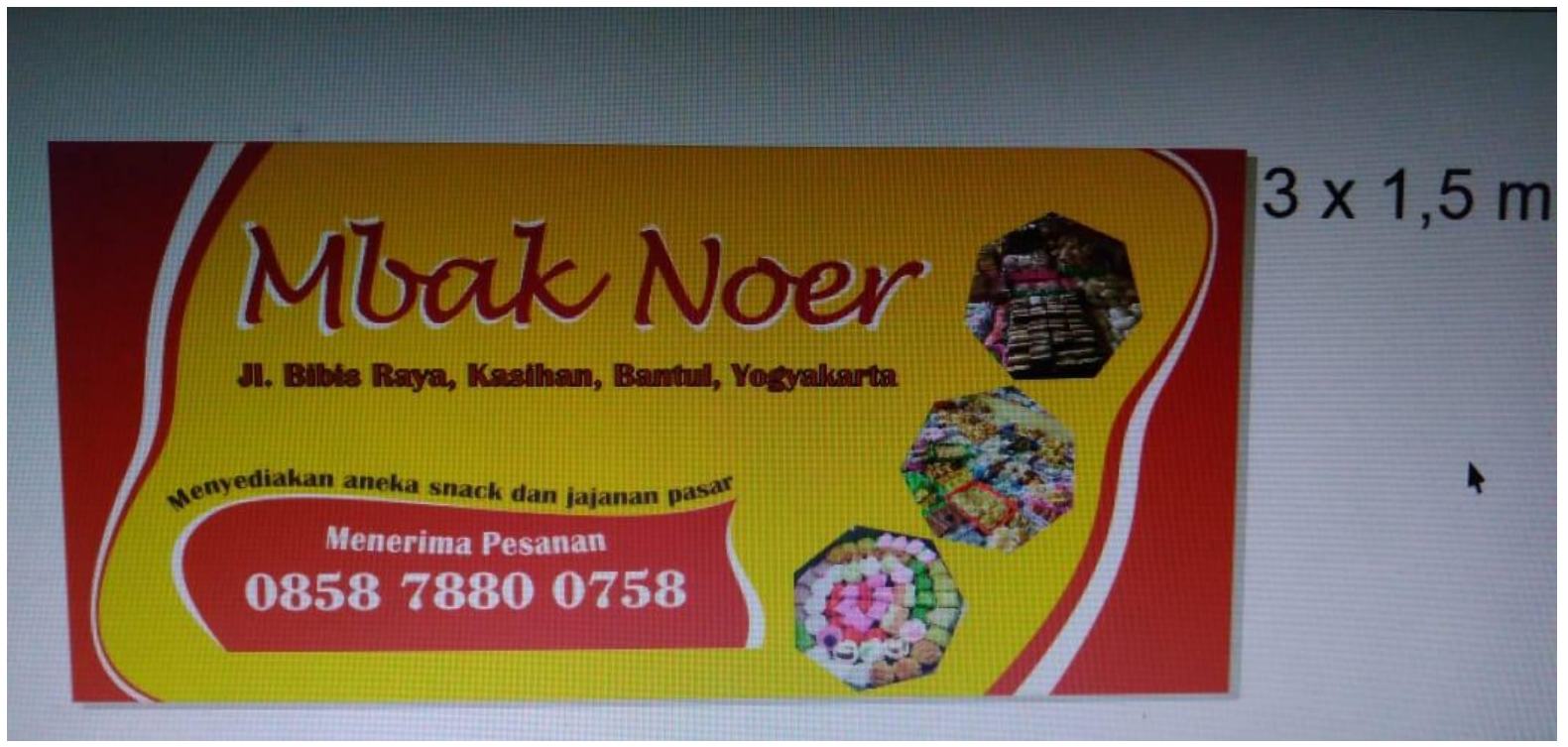



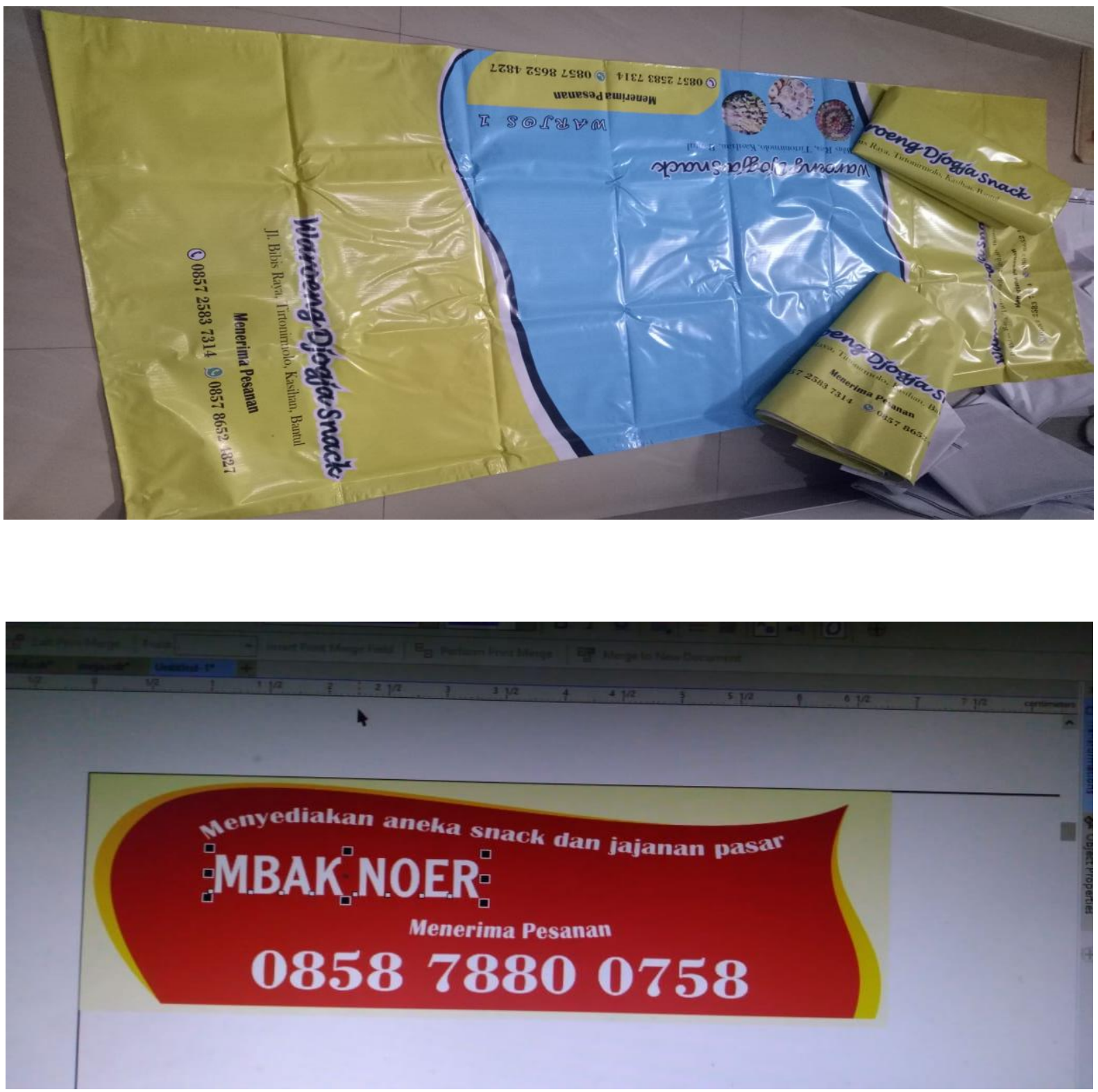

Gambar 3. Rancangan Banner, Taplak, dan Stiker

\section{Pengadaan Alat Saji Makanan dan Stiker}

Pengadaan alat saji berupa tempat makanan dengan kualifikasi "food grade", transparan, dan dapat dibawa dengan aman dari tempat produksi ke tempat Mitra. Alat yang dibeli oleh pengabdi ini sudah dikomunikasikan dengan Mitra. Tempat saji ini adalah milik Mitra, namun akan dibawa oleh supplier. Untuk menunjukkan bahwa tempat saji tersebut adalah milik Mitra, maka tempat saji tersebut diberi label stikel identitas Mitra. Tempat saji dan label tampak pada Gambar 4. 

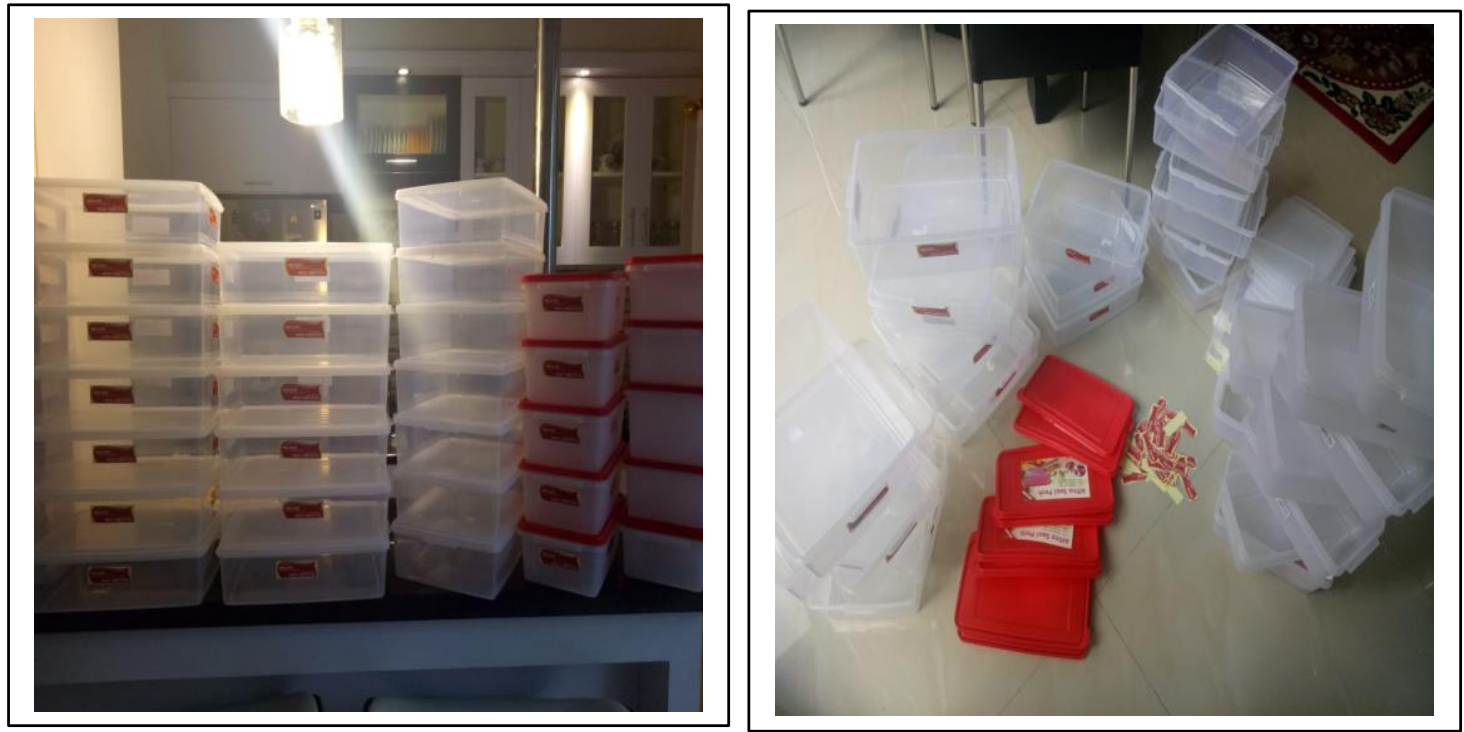

Gambar 4. Tempat Saji Makanan

\section{Penyerahan Tempat Saji dan Pemasangan}

Tempat makanan yang sudah diberi stiker beserta taplak meja, banner, dan spanduk; selanjutnya diserahkan kepada Mitra 1 dan Mitra 2 untuk kemudian dipasang. Penyerahan, pemasangan, hingga penyajian untuk Mitra 1 tampak pada Gambar 5; sedangkan penyerahan dan hasil pemasangan untuk Mitra 2 tampak pada Gambar 6.

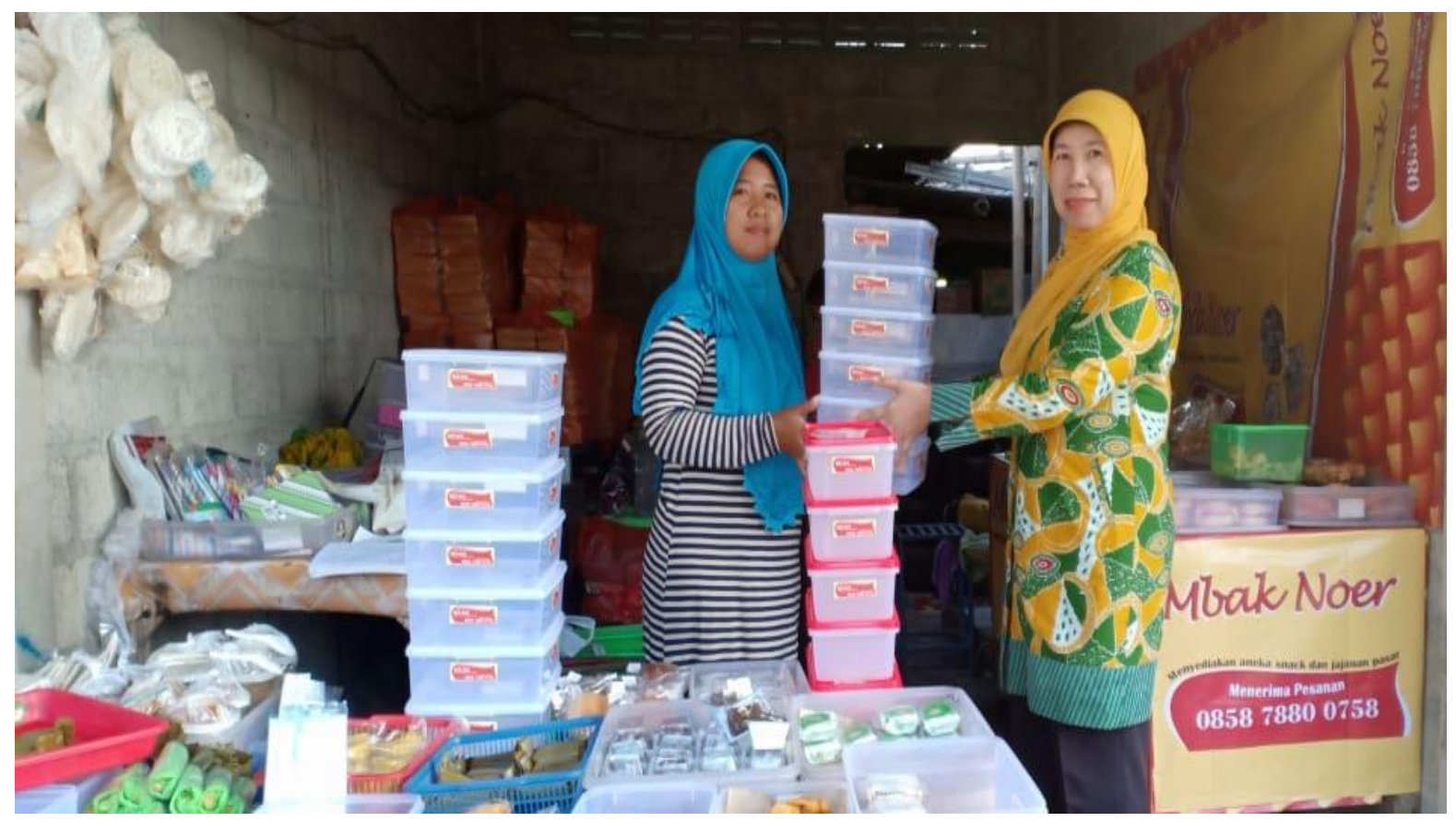




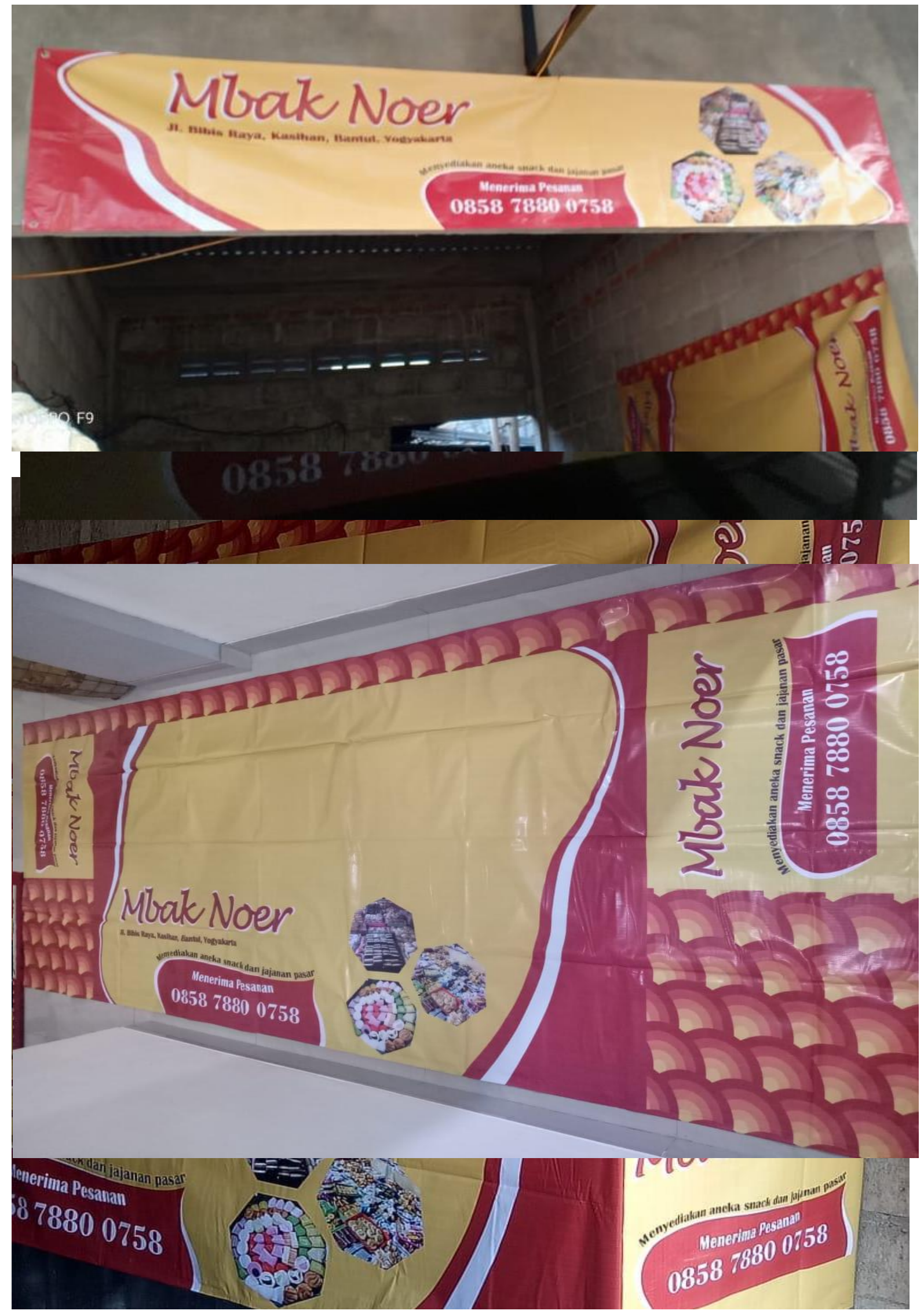




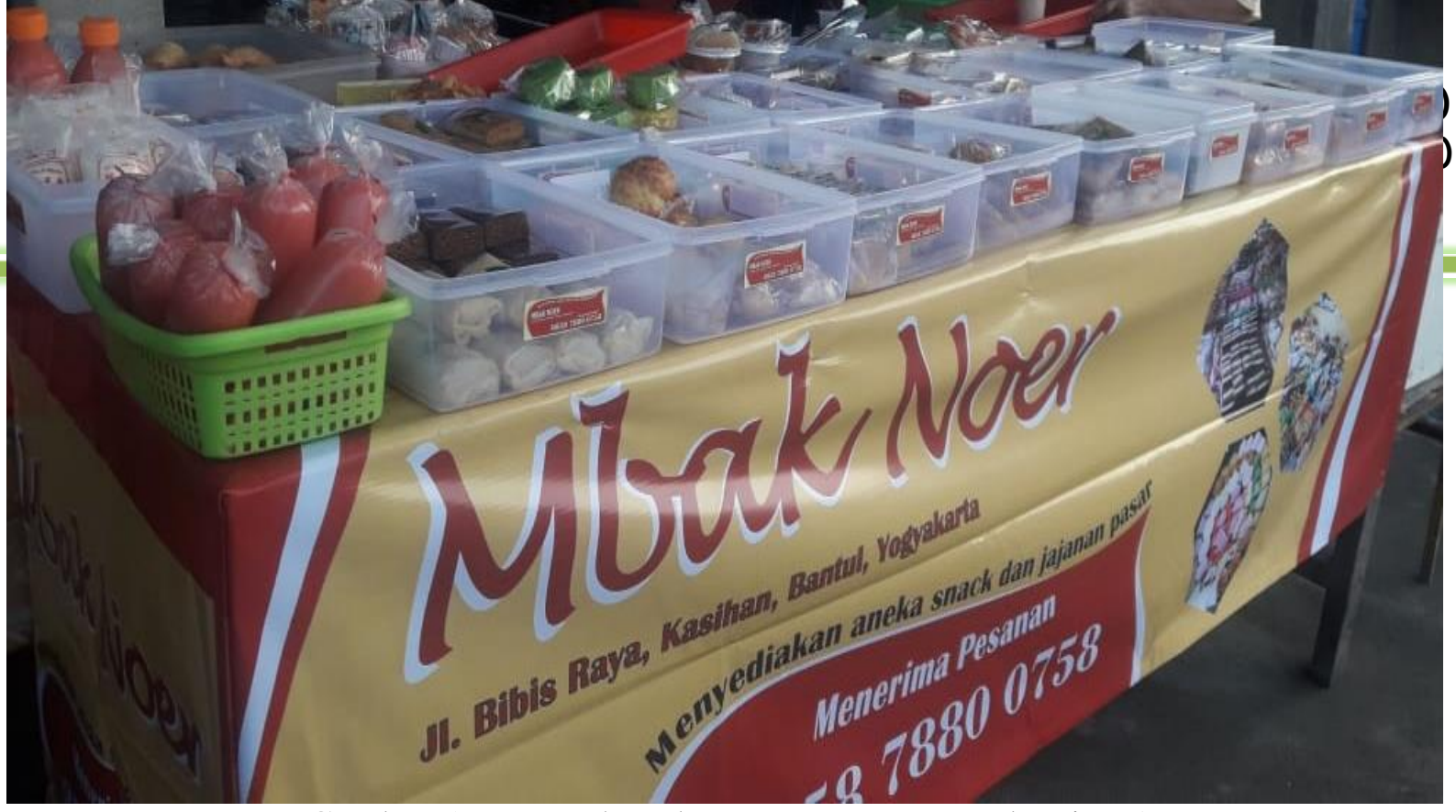

Gambar 5. Penyerahan dan Pemasangan Untuk Mitra 1

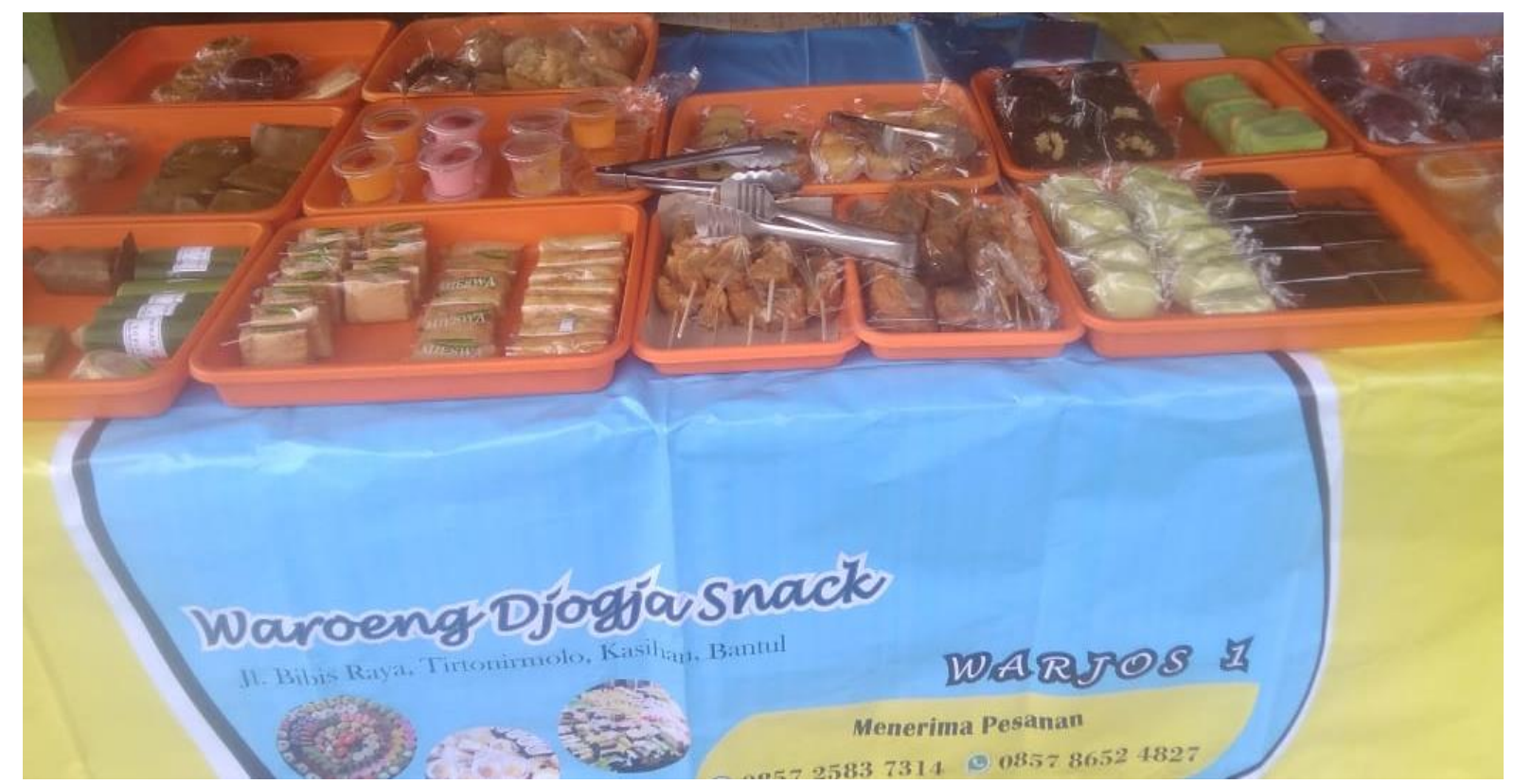

Gambar 6. Penyerahan dan Pemasangan Untuk Mitra 2

Meja yang sebelumnya hanya dengan taplak seadanya, kini tampil lebih estetik dengan desain yang cantik serta diberi label dan identitas, sehingga memudahkan konsumen dalam mengingat dan mengenali warung kuliner yang didirikan Mitra (Gunawan \& Fatmawati, 2018).

\section{Focus Discussion Group dan Pelatihan}

Focus discussion group dilaksanakan untuk Mitra dan supplier, dimana pada supplier pembuat makanan kecil diundang untuk diajak berdiskusi sekaligus diberi edukasi tentang kebersihan, penggunaan bahan baku yang halal, dan penyajian yang baik. Dalam hal pengawasan terhadap produk yang dipasarkan, BPOM memiliki sistem yang dinamakan 
SisPom atau Sistem Pengawasan Obat dan Makanan, sistem tersebut mempunyai fungsi tiga lapis pengawasan yaitu produsen, konsumen, dan pemerintah, sistem tersebut dijalankan untuk menekan sedikit mungkin risiko yang akan terjadi dari saat produk dibuat hingga produk dipasarkan (Ghaisani, 2015).

Pelatihan berupa cara menghitung harga pokok produksi dan pencatatan. Dalam kegiatan pelatihan pencatatan ini diberikan gambaran tentang menghiutng harga pokok produksi pembuatan makanan yang terdiri dari bahan baku,bahan penolong, biaya tenaga kerja, dan biaya overhead pabrik dengan pemahaman ini dapat membantu Mitra dan Supplier dalam mengatur modalnya, karena usaha akan mengalami kemajuan atau kemunduran bahkan tidak terjaga keberlangsungannya tanpa pengelolan modal yang memadai (Mangantar et al.(2016). Pelatihan dan FGD tampak pada Gambar 7.

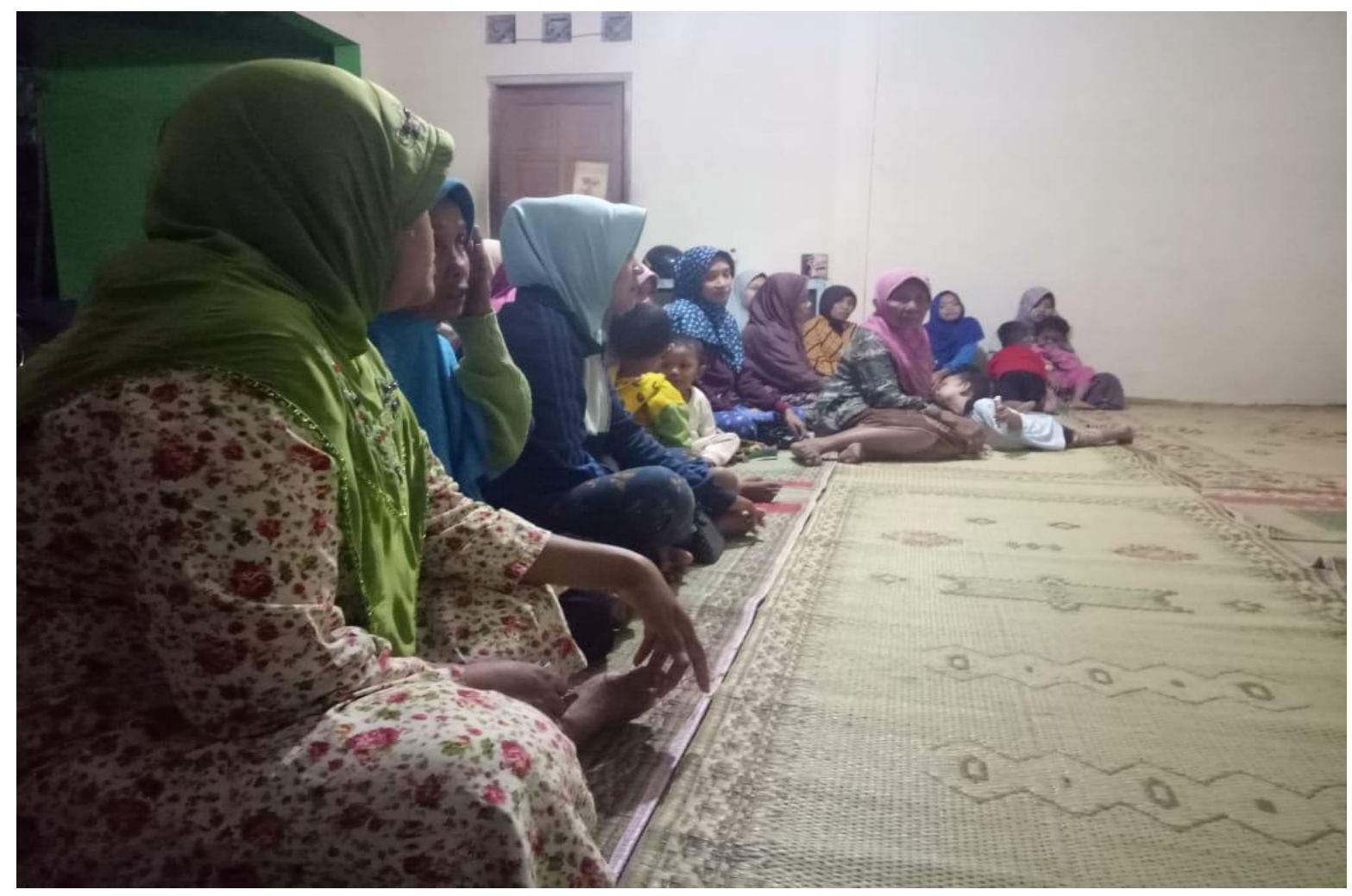




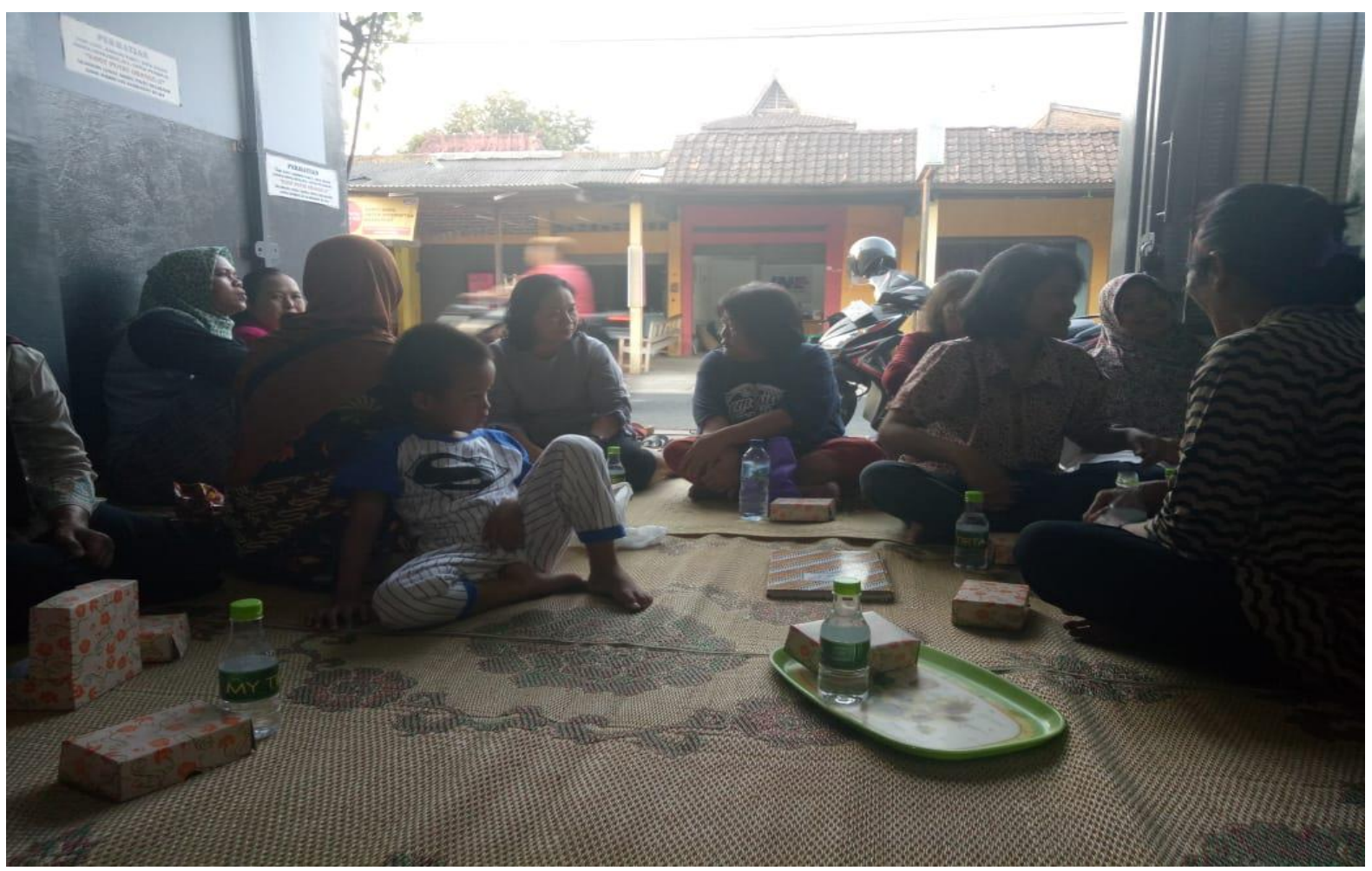

Gambar 7. Pelatihan dan FGD

\section{E. Kesimpulan}

Tujuan program adalah untuk mengembangkan masyarakat yang mandiri secara ekonomi. Mitra usaha dalam program ini adalah usaha kecil pembuatan dan penjualan kue kecil. Permasalahan yang dihadapi oleh Mitra 1 dan Mitra 2 adalah a) Tempat penyajian makanan yang kurang layak dan tidak rapi, b) Tidak ada identitas nama toko, c) meja etalase yang kurang memadai, d) perlengkapan dari pembuat makanan yang kurang layak dan bukan food grade, e) Pencatatan yang belum rapi, dan f) kurangnya edukasi tentang kebersihan. Metode yang dipakai untuk mencapai tujuan tersebut adalah a) Pengadaan tempat penyajian makanan, b) Perancangan dan pembuatan banner, spanduk, dan taplak meja, c) Pengadaan meja etalase yang rapi, d) Pengadaan tempat makanan untuk supplier, e) Pelatihan pencatatan keuangan, dan f) Focus discussion group tentang kebersihan penyajian dan lingkungan sekitar toko. Hasil akhir dari program ini adalah tempat penyajian makanan yang rapi, terpasang baner, spanduk, dan taplak meja dengan identitas Mitra; tersedia meja yang rapi, tersedia tempat makanan dengan symbol food grade, terselenggara pelatihan pencatatan keuangan, 
dan terselenggara focus discussion group. Setelah adanya identitas toko, sudah terjadi beberapa kali pesanan snack box yang tentunya akan meningkatkan pendapatan Mitra.

\section{DAFTAR PUSTAKA}

Ghaisani, M. (2015). Akar Masalah Keamanan Pangan Jajanan Anak Sekolah (Pjas): Studi Kasus Pada Bakso, Makanan Ringan, dan Mi Mazaya Ghaisani. Skripsi, Departemen Ilmu dan Teknologi Pangan Fakultas Teknologi Pertanian ITB, 1-34.

Gunawan, B., \& Fatmawati, I. (2018). PKM Pedagang Kuliner Kaki Lima di Tamantirto Kasihan Kabupaten Bantul Daerah Istimewa Yogyakarta. SINEMAS UAD, 54-69.

Indonesia, B. P. O. dan M. R. (2012). Badan Pengawas Obat Dan Makanan Republik Indonesia. Peraturan Kepala Badan Pengawas Obat Dan Makanan Republik Indonesia.

Mangantar, M., Adolfina, \& Baramuli, D. N. (2016). Usaha Mikro Makanan Tradisional di Kelurahan Dendengan dalam Kota Manado Tentang Manajemen Modal Kerja. Jurnal LPPM Bidang EkoSosBudKum, 3, 80-91.

Maria, M., \& Anshori, M. Y. (2013). Pengaruh Kualitas Produk dan Kualitas Layanan Terhadap Kepuasan Konsumen King Cake. Jurnal Manajemen Teori dan Terapan, (1), 50-51. 